\title{
PERFORMANSI PERTUMBUHAN BIBIT KULTUR JARINGAN RUMPUT LAUT KOTONI (Kappaphycus alvarezii) DI PERAIRAN TELUK VID BANGIR
}

\author{
Robert Pensa Maryunus ${ }^{1}$ dan Rusman Hussein ${ }^{2}$ \\ (1) Balai Budidaya Laut Tual, Dinas Kelautan dan Perikanan Provinsi Maluku; \\ (2) Balai Perikanan Budidaya Laut Lombok, Direktorat Jenderal Perikanan Budidaya, \\ Kementerian Kelautan dan Perikanan. \\ E-mail korespondensi: roby_pm@yahoo.co.id
}

\begin{abstract}
Abstrak
Ketersediaan bibit rumput laut kotoni dalam hal kuantitas, kualitas dan kontinuitas yang memadai merupakan salah satu masalah mendasar bagi pengembangan budidayanya. Penelitian ini bertujuan mengetahui performansi pertumbuhan bibit kultur jaringan rumput laut, K. alvarezii hasil domestikasi Balai Perikanan Budidaya Laut Lombok. Bibit rumput laut setelah ditimbang ditanam dengan metode long line dan diukur beratnya setelah 30 hari pemeliharaan. Sampling paramater kualitas air dilakukan setiap minggu secara periodik. Pada akhir masa pemeliharaan dilakukan penimbangan untuk mengetahui pertumbuhan berat mutlak, berat harian dan pertumbuhan spesifik harian, sekaligus dilakukan observasi untuk mengamati morfologi terhadap thallus yang diuji. Data hasil penimbangan dan observasi dianalisis secara deskriktif kuantitatif dan kualitatif. Hasil yang diperoleh menunjukkan pertumbuhan yang sangat baik dan ukuran bibit yang hampir seragam. Bentuk morfologi bibit memperlihatkan thallus bersih, segar dan berwarna cerah dengan percabangan yang banyak. Keseluruhan parameter kualitas air berada pada kisaran yang layak sampai dengan optimum. Bibit kultur jaringan dianggap layak dikembangkan di perairan Teluk Vid Bangir dan perairan sekitarnya.
\end{abstract}

Kata Kunci : kultur jaringan, performansi, rumput laut kotoni, Teluk Vid Bangir

\section{GROWTH PERFORMANCE OF TISSUE CULTURE COTTONII SEAWEED (Kappaphycus alvarezii) SEEDLING AT VID BANGIR BAY WATERS}

\begin{abstract}
The availability of cottonii seaweed seedling in terms of quantity, quality and sufficient continuity is one of the fundamental problems for cultivation development. This study aimed to investigate the growth performance of red seaweed, $\mathrm{K}$. alvarezii seedlings produced through tissue culture method by domestication of Lombok Marine Aquaculture Center. Seaweed seedling after weighed were planted by long line method for the duration of 30 days. Sampling of water quality parameters was done every week periodically. At the end of observation period, weighing was done to determine the absolute weight growth, daily weight and daily specific growth, as well as observe of thallus morphological tested. The results of weighing and observation data are analyzed by quantitative and qualitative descriptive. The results showed excellent growth and measure of seedling almost uniform. The morphological of seedling was bright colored, fresh and healthy with many forms of thallus. The overall parameters of water quality were at acceptable ranges to the optimum. Seedling of tissue culture is considered feasible to be developed at Vid Bangir Bay waters and surrounding.
\end{abstract}

Keywords : tissue culture, performance, cottonii seaweed, Vid Bangir Bay

\section{PENDAHULUAN}

Salah satu kendala mendasar dalam upaya pengembangan rumput laut kotoni pada sektor hulu adalah ketersediaan bibit dalam kuantitas, kualitas dan kontinuitas yang memadai. Bibit merupakan faktor produksi yang menduduki urutan pertama sebagai biaya variabel terbesar dalam operasional budidaya. Beberapa hasil penelitian menunjukkan bahwa maraknya serangan penyakit ice ice yang menjadi momok bagi pembudidaya, salah satunya disebabkan oleh penggunaan bibit yang tidak berkualitas karena pola penyebaran bakteri patogen penyebab ice-ice juga terjadi secara vertikal dari induk ke stek/thallus muda yang dijadikan sebagai bibit (Yulianto, 2003).

Pemakaian bibit dari sumber yang sama secara berulang-ulang akan berakibat terjadinya "pelunturan genetika", yang berdampak terhadap menurunnya produktivitas, menurunnya kandungan karagenan dan kekuatan gel serta meningkatnya kerentanan terhadap penyakit (Hurtado \& Cheney,
2003; Mulyaningrum, 2018). Kendala dalam pengembangan budidaya rumput laut adalah kualitas bibit rumput laut masih rendah seperti: pertumbuhan kerdil/lambat/tidak maksimal, mudah terserang hama penyakit, mudah tertutupi lumut, tidak tahan terhadap stressor lingkungan serta belum adanya tahapan/proses produksi bibit yang baku (Baedah, 2011).

Salah satu terobosan yang saat ini dilakukan adalah dengan pemakaian bibit kultur jaringan. Saat ini domestikasi bibit kultur jaringan dilakukan oleh Balai Besar Pengembangan Budidaya Laut (BBPBL) Lampung dan Balai Perikanan Budidaya Laut (BPBL) Lombok yang ekspalannya dikembangkan di SEAMEO BIOTROP (Southeast Asian Regional Centre for Tropical Biology) Bogor, melalui beberapa tahapan di laboratorium (Sulistiani et al, 2012). Kultur jaringan pada rumput laut merupakan kultur eksplan (fragmen tallus) secara aksenik dalam media air laut artificial yang diberi zat pengatur tumbuh (ZPT) dan zat pengkaya yang dapat memberikan efek regenerasi (Mulyaningrum, 2018). 
Bibit kultur jaringan yang didomestikasi di BPBL Lombok berdasarkan uji multilokasi di beberapa tempat menunjukkan performansi yang baik dengan tingkat kerentanan yang lebih rendah terhadap serangan penyakit ice ice dan fluktuasi parameter lingkungan perairan serta kandungan karaginan yang lebih tinggi dari bibit lokal (Rusman, 2013). Hal ini diharapkan terus dapat disebarkan ke kebun bibit pada sentra-sentra produksi rumput laut lainnya di Indonesia.

Kota Tual yang terletak di Provinsi Maluku menjadi salah satu sentra produksi rumput laut yang produksinya cukup tinggi. Produksi rumput laut di daerah ini pada tahun 2014 telah mencapai 75.297 ton basah (DKP Maluku, 2015). Berdasarkan hasil studi kelayakan lahan, diketahui bahwa hampir seluruh wilayah pesisir Kota Tual merupakan lokasi yang layak bagi pengembangan budidaya rumput laut, termasuk perairan Teluk Vid Bangir (DKP Maluku, 2012; DKP Maluku, 2014), yang wilayahnya berhadapan langsung dengan UPTD Balai Budidaya Laut Tual, Dinas Kelautan dan Perikanan Provinsi Maluku.

\section{METODE PENELITIAN}

\section{Waktu dan Lokasi Penelitian}

Penelitian ini dilakukan selama 30 hari pada bulan Agustus - September 2015 di perairan Teluk Vid Bangir, Desa Taar, Kecamatan Dullah Selatan, Kota Tual Provinsi Maluku (Gambar 1).

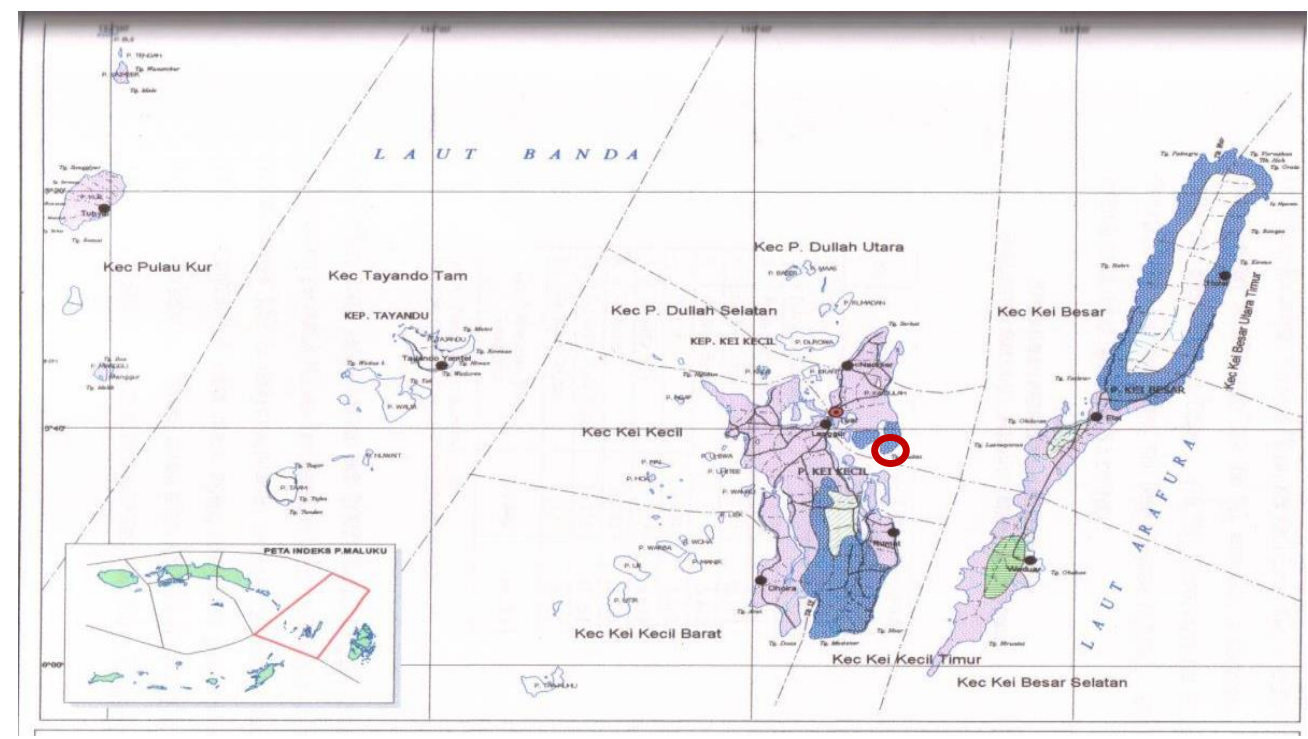

Gambar 1. Peta Stasiun Penelitian

\section{Prosedur Penelitian}

Bibit rumput laut kultur jaringan diperoleh dari BPBL Lombok merupakan thallus pertama hasil pengembangan eksplan di laboratorium. Bibit selanjutnya diaklimatisasi pada bak sistem resirkulasi selama 1 hari sebelum ditanam. Bibit ditimbang dengan berat masing-masing 50 gram (SNI 7673.2.2011) sebanyak 10 titik (rumpun). Penanaman bibit menggunakan metode konstruksi long line. Bibit yang telah ditimbang diikat dengan menggunakan tali PE $\varnothing 1,5 \mathrm{~mm}$ pada 3 tali ris bentang (PE $\varnothing 5 \mathrm{~mm}$ ) secara acak bersamaan dengan bibit lainnya yang tidak ditimbang, masing-masing dengan jarak $25 \mathrm{~cm}$ setiap rumpun. Penempatan rumpun bibit yang diuji diberi kode (penomoran dengan cat pada botol pelampung) dari nomor $1-10$ untuk membedakan dengan titik/ rumpun lainnya. Pada hari ketiga puluh, sesuai dengan standar umur maksimal bibit berdasarkan SNI (SNI 7673.2.2011), setiap rumpun yang telah diberi kode ditimbang untuk mengetahui pertumbuhan berat mutlak, pertumbuhan harian dan pertumbuhan spesifik harian.
Pengukuran parameter kualitas air meliputi suhu $\left({ }^{\circ} \mathrm{C}\right.$, Thermometer) salinitas (ppt, Hand Refraktometer) $\mathrm{pH}$ ( $\mathrm{pH}$ meter digital) dan kecerahan ( $\mathrm{m}$, secchi disk) dilakukan setiap minggunya secara periodik sebanyak satu kali pada jam 12 siang. Pengontrolan dan pembersihan rumput laut dilakukan setiap hari dengan cara menggoyang-goyangkan bibit rumput laut. Selama periode penelitian dilakukan pengamatan terhadap kemungkinan adanya serangan penyakit dan hama serta tumbuhan penempel (efifit). Pengamatan secara visual pada saat penimbangan bibit hari ke 30 untuk mengamati bentuk morfologi bibit.

\section{Analisis Data}

Pegukuran berat yang dilakukan dengan menggunakan formula sebagai berikut :

a) Pertumbuhan Mutlak:

$$
\mathbf{G}=\mathbf{W t}-\mathbf{W o}
$$

(Fortes, 1989)

dimana :

$\mathrm{G} \quad=$ Pertumbuhan Mutlak $(\mathrm{g})$ 
Wo = Berat bibit awal $(\mathrm{g})$

$\mathrm{Wt}=$ Berat bibit pada hari ke-t $(\mathrm{g})$

Pertumbuhan Harian :

dimana :

$$
\mathbf{D G}=\frac{\mathbf{W t}-\mathbf{W o}}{\mathbf{t}} \quad \text { (Fortes, 1989) }
$$

DG = Pertumbuhan harian $(\mathrm{g} /$ hari $)$

Wo = Berat bibit awal $(\mathrm{g})$

$\mathrm{Wt}=$ Berat bibit pada hari ke-t $(\mathrm{g})$

$\mathrm{t}=$ Lama waktu pemeliharaan (hari)

Pertumbuhan Spesifik Harian :

$$
\text { SGR }=\frac{1 \text { n Wt }-1 \text { n Wo }}{T} \times 100 \%
$$

(Castell \& Tiews, 1980)

$$
\begin{array}{ll}
\text { dimana : } & \\
\text { SGR } & =\text { Pertumbuhan spesifik harian }(\%) \\
\mathrm{Wo} & =\text { Berat bibit awal }(\mathrm{g}) \\
\mathrm{Wt} & =\text { Berat bibit pada hari ke-t }(\mathrm{g}) \\
\mathrm{t} & =\text { Lama waktu pemeliharaan (hari) }
\end{array}
$$

Pengamatan terhadap bentuk morfologi di akhir masa pemeliharaan dilakukan melalui metode observasi. Data yang diperoleh selanjutnya dianalisis secara deskriktif kuantitatif dan kualitatif.

\section{HASIL DAN PEMBAHASAN}

\section{Berat dan Morfologi}

Data berat awal, berat akhir dan analisis pertumbuhan mutlak, pertumbuhan harian serta pertumbuhan spesifik harian bibit rumput laut kultur jaringan tersaji pada tabel 1 .

Tabel 1. Berat Awal, Berat Akhir, Pertumbuhan Mutlak, Pertumbuhan Harian dan Pertumbuhan Spesifik Harian Bibit Rumput Laut Hasil Kultur Jaringan Setelah Pemeliharaan Selama 30 hari.

\begin{tabular}{cccccc}
\hline Nomor Rumpun & Wo $(\mathbf{g})$ & $\mathbf{W t}(\mathbf{g})$ & $\mathbf{G}(\mathbf{g})$ & $\mathbf{D G}(\mathbf{g} / \mathbf{h a r i})$ & $\mathbf{S G R}(\boldsymbol{\%})$ \\
\hline 1. & 50,00 & 370,00 & 320,00 & 10,67 & 6,67 \\
2. & 50,00 & 360,00 & 310,00 & 10,33 & 6,58 \\
3. & 50,00 & 370,00 & 320,00 & 10,67 & 6,67 \\
4. & 50,00 & 380,00 & 330,00 & 11,00 & 6,76 \\
5. & 50,00 & 360,00 & 310,00 & 10,33 & 6,58 \\
6. & 50,00 & 370,00 & 320,00 & 10,67 & 6,67 \\
7. & 50,00 & 365,00 & 315,00 & 10,50 & 6,63 \\
8. & 50,00 & 380,00 & 330,00 & 11,00 & 6,76 \\
9. & 50,00 & 370,00 & 320,00 & 10,67 & 6,67 \\
10. & 50,00 & 360,00 & 310,00 & 10,33 & 6,58 \\
$\bar{x}$ & 50,00 & 368,50 & 318,50 & 10,62 & 6,66 \\
stdev & 0,00 & 7,47 & 7,47 & 0,25 & 0,07 \\
\hline
\end{tabular}

Sumber: Data Hasil Penimbangan dan Analisis (2015)

Berdasarkan Tabel 1 terlihat bahwa pada umur 30 hari rata-rata pertumbuhan mutlak $(\mathrm{G})$ yakni 318,50 gram atau berkisar 6,37 kali dari berat bibit awal Bibit rumput laut yang diperoleh dari BPBL Lombok merupakan bibit thallus pertama dari serangkaian proses aklimatisasi di laboratoriuum, bak dan di perairan laut (Rusman, 2013). Bibit hasil kultur jaringan tersebut meskipun belum lama beradaptasi dengan perairan baru namun telah menunjukkan performa pertumbuhan yang baik yakni diatas 5 kali dari berat bibit awal meskipun belum mencapai umur panen 45 hari.

Pertumbuhan harian (DG) yang didapatkan menunjukkan bahwa setiap harinya rata-rata pertambahan berat adalah 10,62 gram. Sedangkan pertumbuhan spesifik harian (SGR) berkisar antara $6,58-6,76 \%$. Laju pertumbuhan yang dianggap menguntungkan adalah diatas $3 \%$ pertambahan berat per hari (Puslitbangkan 1991; Anggadiredja et al., 2006) . Berdasarkan nilai G, DG dan SGR menunjukkan pertumbuhan yang hampir seragam, dimana nilai yang diperoleh lebih tinggi dari batasan minimal yang dipersyaratkan. Hal ini mengindikasikan bahwa bibit rumput laut kultur jaringan mampu beradaptasi dengan baik pada lingkungan perairan Teluk Vid Bangir. Menurut Kadi \& Atmadja (1988) cepat atau lambatnya pertumbuhan rumput laut tergantung dari jenis rumput laut dan mutu lingkungan perairannya.

Bentuk morfologi bibit setelah pemeliharaan 30 hari memperlihatkan warna thallus yang bersih, segar dan berwarna cerah dengan percabangan yang banyak (Gambar 2). Menurut Parenrengi et al (2011), kriteria bibit rumput laut yang baik antara lain: thallus rumput laut secara morfologi bersih, segar dan muda dimana tanaman yang segar ditandai dengan thallus yang keras dan berwarna cerah (warna khas rumput laut); bebas dari penyakit; memiliki cabang yang banyak, rimbun dan berujung agak runcing serta berukuran seragam. 


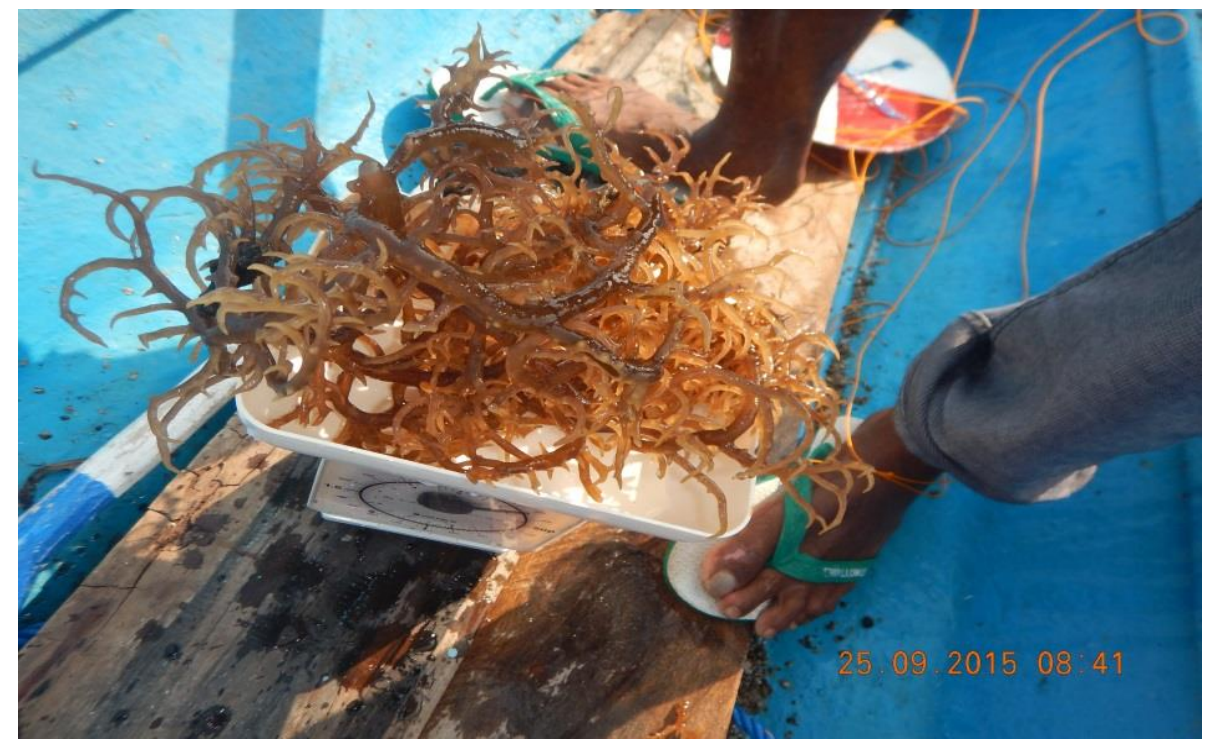

Gambar 2. Bentuk Morfologi Bibit Rumput Laut Kultur Jaringan Setelah Pemeliharaan Selama 30 hari (Foto Lapangan).

Sumber: Dokumentasi Penulis (2015)

Selama masa pemeliharaan tidak ditemukan adanya serangan hama dan penyakit ice ice serta tumbuhan penempel. Hal ini selain disebabkan oleh kondisi lingkungan yang mendukung juga tidak terlepas dari kegiatan pengontrolan dan pembersihan yang dilakukan rutin setiap hari.

\section{Kualitas Air}

Data pengamatan kualitas air selama periode pengamatan tersaji pada Tabel 2. Berdasarkan data yang diperoleh suhu berkisar antara $27-28{ }^{\circ} \mathrm{C}$. Kisaran suhu yang layak untuk budidaya rumput laut adalah $27-30{ }^{\circ} \mathrm{C}$ (Neish, 2005). Salinitas antara $30-$ $31 \%$, dimana kisaran salinitas yang dianjurkan menurut DKP (2006) adalah $28-35 \%$. Sedangkan untuk pH didapatkan kisaran antara 7,7 - 7,8 yang berarti berada pada kisaran $\mathrm{pH}$ optimum yakni 7,2 8,3 (Kadi \& Atmadja, 1988).

Tabel 2. Nilai Parameter Kualitas Air Selama Periode Penelitian.

\begin{tabular}{llcccc}
\hline \multirow{2}{*}{ No. } & \multicolumn{2}{c}{ Hari/Tanggal } & \multicolumn{4}{c}{ Paramater Kualitas Air } \\
\cline { 3 - 6 } & & Suhu $\left({ }^{\circ} \mathbf{C}\right)$ & Salinitas $(\%)$ & pH & Kecerahan (m) \\
\hline 1. & Senin, 24 Agustus 2015 & 27 & 30 & 7,8 & 7,10 \\
2. & Senin, 31 Agustus 2015 & 28 & 30 & 7,7 & 6,15 \\
3. & Senin, 07 September 2015 & 27 & 30 & 7,8 & 6,55 \\
4. & Senin, 14 September 2015 & 28 & 31 & 7,7 & 6,55 \\
5. & Senin, 21 September 2015 & 27 & 30 & 7,8 & 7,30 \\
\hline
\end{tabular}

Sumber: Hasil Pengukuran (2015)

Nilai kecerahan didapatkan berkisar antara 6,15 $7,30 \mathrm{~m}$, lebih besar dari nilai minimal yang dipersyaratkan yakni $5 \mathrm{~m}$ (Sujatmiko \& Angkasa, 2004). Dengan demikian berdasarkan beberapa parameter kualitas air yang diamati menunjukkan bahwa nilai yang didapatkan semuanya berada dalam kisaran layak sampai dengan optimum bagi pertumbuhan rumput laut.

\section{SIMPULAN}

Pertumbuhan dan adaptasi serta bentuk morfologi bibit rumput laut kultur jaringan hasil domestikasi Balai Perikanan Budidaya Laut (BPBL)
Lombok di perairan Teluk Vid Bangir Kota Tual menunjukkan performansi yang sangat baik sehingga layak dikembangkan di perairan tersebut dan sentrasentra produksi rumput laut di sekitarnya.

\section{UCAPAN TERIMA KASIH}

Ucapan terima kasih dan penghargaan disampaikan kepada staf teknis UPTD Balai Budidaya Laut (BBL) Tual masing-masing adalah: Charles Tabalubun, Melkisedek Oraile dan John Rahayaan yang telah banyak membantu pelaksanaan penelitian ini di lapangan. 


\section{DAFTAR PUSTAKA}

Anggadiredja, J. T., Zatnika, A., Purwoto, H \& Istini, S. (2006). Rumput Laut: Pembudidayaan, Pengolahan \& Pemasaran Komoditas Perikanan Potensial. Jakarta: Penerbit Penebar Swadaya. 148 hal.

Baedah, M. A. (2011). Perlunya Standar Operasional Prosedur (SPO) Pengadaan Bibit Rumput Laut di Sulawesi Tengah. Makalah. Palu: Dinas Kelautan dan Perikanan Provinsi Sulawesi Tengah.

BSN. (2011). SNI 7673.2:2011 : Produksi Rumput Laut Kotoni (Eucheuma cottonii) Bagian 2 Metode long line. Jakarta: Badan Standardisasi Nasional

Castell, J. D., \& Tiews, K. (1980). Report of the EIPAC, IUNS and ICES Working Group on the Standardization of Metodology in Fish Nutrition Research. Hamburg: Germany EIFAC Tech. Paper. 24 pp.

DKP. (2006). Petunjuk Teknis Budidaya Laut Rumput Laut Eucheuma spp. Direktorat Produksi. Direktorat Jenderal Perikanan Budidaya. Jakarta: Departemen Kelautan dan Perikanan.

DKP Maluku. (2015). Laporan Statistik Perikanan Budidaya Tahun 2014. Ambon: Dinas Kelautan dan Perikanan Provinsi Maluku.

DKP Maluku. (2014). Penyusunan Peta Potensi Kawasan Budidaya Perikanan Maluku. Naskah Akademik. Ambon: Dinas Kelautan dan Perikanan Provinsi Maluku.

DKP Maluku. (2012). Rencana Zonasi Wilayah Pesisir dan Pulau-Pulau Kecil Gugus Pulau VIII (Kepulauan Kei). Naskah Akademik. Ambon: Kerjasama DKP Provinsi Maluku CV Mitra Karya Konstruksi.

Fortes, M. D. 1989. Seagrasses: a resource unknown in the ASEAN region. ICLARM Education. Series 5. Manila. Philiphines: International Centre for Living Aquatic Resources Management.

Hurtado, A.Q., \& Cheney, D.P. (2003). Propagule Production of Eucheuma denticulatum (Burman) Collins et Harvey by Tissue Culture. Bot. Mar., 46(4):338-341.

Kadi, A \& Atmadja, W.S. (1988). Rumput Laut (Algae): Jenis, Reproduksi, Produksi, Budidaya dan Pasca Panen. Jakarta: LIPI. 71 hal.

Mulyaningrum, S. R. H. (2018). Mengapa perlu kultur jaringan rumput laut ?. Diakses pada tanggal 29 Agustus 2018. Error! Hyperlink reference not valid. uploads/Newsletterkultur jaringan_Januari_2.pdf
Neish, I. C. (2005). The Eucheuma Seaplant Handbook; Vol I: Agronomy, Biology and Culture System. Seaplantnet Technical Monograph. 36 hal.

Parenrengi, A., Rachman Syah \& Suryati, E. (2011). Budidaya Rumput Laut Penghasil Karaginan (Karaginofit). Seri Teknologi Untuk Minapolitan. Edisi Revisi. Jakarta: Balai Riset Perikanan Budidaya Air Payau, Badan Pengembangan dan Penelitian Kelautan dan Perikanan, Kementerian Kelautan dan Perikanan. 54 hal.

Puslitbangkan. (1991). Petunjuk Teknis Budidaya Rumput Laut. Jakarta: Pusat Penelitian dan Pengembangan Perikanan, Departemen Pertanian.

Rusman. (2013). Petunjuk Teknis Domestikasi Bibit Kultur Jaringan Rumput Laut Kotoni (Kappaphycus alvarezii). Lombok Barat: Balai Budidaya Laut Lombok. 11 hal.

Sujatmiko, W \& Angkasa, W. I. (2004). Teknik Budidaya Rumput Laut dengan Metode Tali Panjang. Jakarta: Badan Penelitian dan Pengkajian Teknologi.

Sulistiani, E., Soelistyowaty, D. T. \& Yani, S. A. (2012). Callus induction and filaments regeneration from callus of cottonii seaweed (Kappaphycus

alvarezii (Doty) collected from Natuna Island, Riau Islands Province. BIOTROPIA., 19(2):103114.

Yulianto, K. (2003). Pengamatan Penyakit "ice-ice" dan Alga Kompetitor Fenomena Penyebab Kegagalan Panen Budidaya Rumput Laut

(Kappaphycus alvarezii) (C.) Agardh di Pulau Pari, Kepulauan Seribu Tahun 2000 dan 2001. Prosiding Seminar Riptek Kelautan Nasional: 100-103. 